\title{
THE INTEGRATION OF COMPUTER USE IN EDUCATION
}

\author{
JAN VAN DEN AKKER, PAUL KEURSTEN and TJEERD PLOMP
}

\author{
Department of Education, University of Twente, P.O. Box 217, 7500 AE Enschede, \\ The Netherlands
}

\begin{abstract}
There is an increasing awareness that disappointing experiences with the introduction of computers in education are a consequence of insufficiently taking into account factors that are crucial when introducing change in educational settings. Many of the problems in the literature show great similarity with the kind of problems often experienced in curriculum implementation. In this context the endeavors to make computer use an integrated part of classroom activities are analyzed. Emphasis will be laid on the interaction between teachers and courseware; elements for a more effective strategy for the integration of computer use in educational practice will be presented, with special attention to the design of support materials as an essential part of courseware.
\end{abstract}

\section{Introduction}

Despite many national and local initiatives, examples of successful computer use in classroom practice are still relatively rare. In many countries the number of computers in schools has considerably increased in recent years. However, little progress has been made: still few teachers are actual users; software use is often restricted to drill and practice type; the alignment with the curriculum pattern is poor. Research results (of both surveys and case studies) from many countries point to the conclusion that there is still a long way ahead before computer use will be effectively integrated in most classrooms (see e.g. Becker, 1986; Office of Technology Assessment [OTA], 1988, for the USA; Chomienne, 1988; Olson \& Eaton, 1986, for Canada; Cox, 1987, for the U.K.; Inspectorate, 1986; Plomp \& Van den Akker, 1988, for the Netherlands).

There is an increasing awareness that these disappointing experiences are a consequence of insufficiently taking into account factors that are crucial when introducing change in educational settings. Many of the reported problems that schools and teachers face when implementing computer use show great similarity with the kind of problems often experienced in curriculum implementation (cf. Fullan, Miles, \& Anderson, 1987; Sheingold, Martin, \& Endreweit, 1987; Walker, 1986). For that reason we would like to analyze the endeavor to make computer use an integrated part of classroom activities 
from a curriculum implementation perspective. We shall start with an overview of the variables that can influence the process and outcomes of curriculum implementation. For the different categories of those variables we shall then discuss the literature on computer use in education. Emphasis will be laid on the interaction between teachers and courseware. Based on this problem analysis we shall present elements for a more effective strategy for the integration of computer use in the educational practice. Special attention will be paid to the design of (written) support materials as an essential part of courseware.

\section{An Overview of Factors Affecting Implementation}

- Drawing upon the work of Fullan (1982) and of Van Velzen, Miles, Ekholm, Hameyer, and Robin (1985), we propose a framework for discussing factors influencing the implementation of innovations in the educational practice by distinguishing four categories of variables:

- national (and/or state and/or district) context;

- characteristics of the school (organization);

- external support;

- characteristics of the innovation itself.

Within each category several variables can be mentioned:

\section{National context}

- central legislation and regulations;

- system of policy formation and decision making in educational affairs;

- time, resources and facilities made available for an innovation;

- proclaimed values and aims about an innovation;

- attitude of politicians and (other) opinion leaders about an innovation.

\section{School organization}

- experiences with earlier innovations;

- role of the school leader(s);

- methods of decision making;

- available facilities (time, money, materials);

- internal co-operation and mutual support;

- distribution and exchange of information.

\section{External support}

- inservice training;

- assistance with internal staff development;

- coaching and guidance for individual teachers;

- personal contacts with experts and colleagues from other schools.

\section{Innovation characteristics}

- relevance of the innovation for needs and problems of users;

- clarity of the goals and practical meaning of a change proposal; 
- complexity of innovation requirements, especially in teaching behavior;

- quality and practicality of the innovation products.

In the next sections we shall first summarize literature on the integration of computer use, as far as it relates to the first three categories (national context, school organization, and external support). We refer to those categories of variables as the conditional factors, because they are conditional for the ultimate use of products by teachers in their daily work. Afterwards we shall focus our attention on the characteristics of the innovation product itself in relation to the teacher's role.

\section{Conditional Factors for the Integration of Computer Use}

Which research results about conditional factors can be found in the literature on computer use in education? We do not intend to offer an exhaustive overview of this literature, but restrict ourselves to a summary of some selected publications, with an emphasis on empirically based sources.

\section{National Context}

Still little empirical research is done about the impact of variables in the national (state/district) context on the actual use of computers in the school practice. Descriptions of national policies on information technology in many countries are available (e.g. Beishuizen, Tobin \& Weston, 1988), but focused research efforts in this area are hard to find. Broad attention for policy variables is given by Fullan et al. (1987) in their study on the implementation of the new information technology in Ontario schools. Apart from obvious tasks as investing in hardware, software development, research, teacher training and the like, policy makers should also play a stimulating role in the planning and co-ordination of implementation activities. Proclamation of new aims for the educational system and encouragement "from above" for initiatives and activities in the field can be helpful for the many participants in the innovation.

\section{School Organization}

The influence of the school organization on the implementation of computer use has been studied more frequently. The results usually confirm the findings from the more general innovation literature.

Encouragement and support from school administrators and principals are of vital importance (Carmichael, Burnett, Higginson, Moore, \& Pollard, 1985; Cox, Rhodes, \& Hall, 1988; Fullan et al., 1987). Help from principals is especially necessary in providing for facilities for training, the purchase of hardware and software, the rearrangement of timetables and other organizational measures.

Also conducive to the implementation process is a positive school climate where teachers give mutual support by exchanging ideas and experiences and by providing feedback (Carmichael et al., 1985; Cox, 1987; Inspectorate, 1986). 
A beneficial role can also be played by computer coordinators, especially if they combine computing expertise with strong interpersonal and organizational skills (Strudler \& Gall, 1988). Also measures have to be taken to secure long term supplies and maintenance of hardware and software (Bitter \& Gore, 1986; Wagshal, 1986).

\section{External Support}

A growing body of experience and research data has become available about effective components of inservice training and other forms of external support for schools and teachers in the use of computers.

A criticism on past inservice approaches is that the emphasis on technical aspects was too strong, while too little attention was paid to the integration of computer use in the daily classroom practice and also to the skills in selecting and evaluating courseware (Chomienne, 1988; D'Arcy \& Gardner, 1988; Wiske et al., 1988). Teachers need a strong support to overcome their (initial) problems of uncertainty and their concerns about changing teacher/student relationships and about accountability (OTA, 1988).

There is a growing consensus about characteristics of inservice training that can increase its effectiveness (OTA, 1988; Stecher \& Solorzano, 1987): appropriate balance between lecture and (guided) practice; detailed curriculum guides and plans for the course plus lesson-related materials and hand-outs; clear training objectives; inservice lessons linked to teachers' own instructional practice; peer interaction, including communication during hands-on activities; strategies for teaching heterogeneous groups; follow-up support and guidance.

This (selective) literature review indicates a rough similarity between conditional factors for both integration of computer use and curriculum implementation. Future, more focused, research activities are necessary to sharpen our insights in this area.

\section{Product Characteristics and the Teacher's Role}

"Educators and educational researchers consistently cite one factor as central to the full development of technology's use in the schools - the classroom teacher" (OTA, 1988 , p. 87). For that reason it is important to take a closer look at the changes facing teachers at the implementation of computer use in their classroom practice. As Fullan (1982) has pointed out, nearly every innovation requires teachers to change on several dimensions: the use of new materials, alterations in their teaching behavior, and changes in their beliefs and attitudes. In this section we want to explore how certain characteristics of the new materials (especially courseware) can influence changes in teaching behavior and beliefs.

From the general innovation literature we know that there are several product characteristics that can influence the fate of a certain innovation. First, we present a brief overview of this literature. Then we shall use this as a filter to screen the literature on computer use in education. 


\section{Influential Product Characteristics}

Well-known discourses about influential (product) characteristics of innovations are delivered by Rogers and Shoemaker (1971) who describe features like observability, complexity, compatability, and relative advantage, and by Doyle and Ponder (1977-78) who refer to the practicality ethic of teachers, with criteria like instrumentality, congruence, and cost. An authorative summary of these characteristics is provided by Fullan (1982; see also Fullan et al., 1987). He mentions the following characteristics, elucidated by some central questions:

\section{Need and relevance}

What is the need for and the appropriateness of the change? What is the priority of the efforts to implement the innovation relative to other concerns?

\section{Clarity}

How clear are the goals and essential features of the innovation? How clear are the practical implications for the users?

\section{Complexity}

How many components of instructional practice are affected and how much do they differ from existing practices and beliefs? How difficult is it to learn the necessary changes?

\section{Quality and practicality}

How well developed and tested are the products? How certain is the impact of the innovation? What is the trade-off between the actual benefits and the personal and organizational costs?

Weaknesses in one or more of these characteristics usually cause major obstacles for implementation. Fullan (1982, p. 62) underlines the importance of individual perceptions in this respect: "Implementation is a problem of individuals developing meaning in relation to specific policy or program directions." Although materials alone can never be sufficient for the implementation of innovation proposals by broad target groups of teachers, the potential influence of materials is great. Well designed and validated products can contribute substantially to the realization of educational changes (Crandall and Associates, 1982; Emrick \& Peterson, 1978; Van den Akker, 1988c).

We proceed now with a short overview of research findings about the interaction between product characteristics and teachers in the domain of computer use.

\section{Courseware Quality and Teachers' Problems}

There is a wide dissatisfaction about the quality of educational software and courseware (OTA, 1988). Some conclusions are:

- Much educational software is isolated material, badly attuned to the curriculum 
(content, materials, strategies) in use (Inspectorate, 1986; Woodhouse \& Jones, 1988). Often computer use cannot be a process of simply incorporating new into old, but it requires reshaping what was there (Hawkins \& Sheingold, 1986). But also a warning is in place: if the software closely relates to the existing curriculum, it can indeed be easier for the teachers $t 0$ use, but then it is often seen as just an "extra" and not fully integrated in the day to day practice (Cox, 1987). Thus, software should either support the goals of the existing curriculum or meet the needs for a curriculum change (Mallatratt, 1988).

- Much software has been developed for use by individual students, not taking into account the usual whole-class teaching and the practical constraints of a classroom with limited numbers of computers (Centre for Educational Research and Innovation [CERI], 1986). This restriction places a considerable demand on the planning and management skills of teachers.

- Much software is poorly documented (Jorde, 1985). User guides contain mainly "technical" information about operational aspects of the software. Support (print) materials for the teacher with suggestions how to integrate the program in the instructional process is frequently lacking (Inspectorate, 1988).

- "Most software does not yet sufficiently exploit the capacity of the computer to enhance teaching and learning. ... Drill and practice software continues to dominate all subject areas" (OTA, 1988, p. 122). Furthermore, much of the early generation of software can be characterized by the "Quiz Syndrome" (Mackey, 1987). An innovation which appears to bring just one long question-answer routine gets a bad name.

- The available educational software covers only parts of the different subject matter domains (Inspectorate, 1988); most software is just "piecemeal" (Williams \& Williams, 1984).

The lack of sufficient high quality materials obstructs the integration of computer use into the daily practice. Problems many teachers experience are the following:

- For various reasons it is difficult to select suitable software. Not only is software often poorly documented, but also many teachers lack the knowledge and skills for an effective evaluation of the software quality (Knupfer, 1986; Preece \& Jones, 1985). Moreover, there are only limited possibilities to preview potentially useful software before purchase (Balla, Gow, \& Burton, 1986; Mallatratt, 1988).

- Teachers often lack technical skills in using computers and software (CERI, 1986; Ridgway et al., 1984). This often leads to uncertainty, especially when the level of computer familiarization of the teacher is the same as or even lower than that of the students (Carmicheal et al., 1985; Heywood \& Norman, 1988). A consequence of this phenomenon may be that educational computing will be restricted to the limited level of expertise of the teacher.

- Teachers often experience unanticipated problems with their instructional roles (Carmicheal et al., 1985; Cuban, 1986; Hawkins \& Sheingold, 1986; Wiske et al., 1988). Computers challenge teachers' existing instructional routines by requiring a shift from expository teaching towards a role in which the teacher is more of a partner and guide of the students. Many teachers feel uncomfortable about these changes and therefore try to minimize them (Elder, Gourlay, Johnstone, \& Wills, 1987; Olson, 1988; Plomp, Steerneman, \& Pelgrum, 1988). This factor is particularly 
important because research has shown that the way a teacher integrates computer use through his ongoing instructional decisions is critical to the impact of computer use on learners and learning results (Wilson, 1988). Cox et al. (1988) observe that teachers frequently lack knowledge and skills for effective stimulation of students' microcomputer activities, and thus children fail to learn what they might learn with judicious teacher intervention.

- Teachers experience many practical problems when they start to use computers (Carmicheal et al., 1985; Elder et al., 1987; Inspectorate, 1986). Computer use demands from teachers many time-consuming management and organizational activities. Wiske et al. (1988) conclude that the major barrier for computer use is that it is unclear for teachers how the potential contribution of computer use can outweigh the costs involved.

In summary we may conclude that the research on the integration of computer applications in education reveals many similar problems as described in the literature on curriculum implementation (cf. Fullan et al., 1987). Most factors that influence curriculum implementation also influence the integration of computer use in the instructional practice.

\section{An Infusion Approach for the Integration of Computer Use}

In this section we will try to identify elements of an effective strategy for the integration of computer use in education by analogy reasoning with approaches of effective curriculum implementation.

Most teachers, if they are using computers at all, are still inexperienced users; the great majority are in the initial implementation phase. In this stage small-scale successful experiences are an important factor in stimulating the use of the innovation by teachers, both in the field of curriculum implementation (Van den Akker, 1988b) and computer integration (Fullan et al., 1987). There are two components of successful experiences: first, the students attain clear learning results; second, the teacher succeeds in an effective lesson execution without major problems, and is aware of his own contribution in this respect.

Such successful experiences can only take place when teachers have high quality courseware at their disposal. We define courseware as: a package comprising computer software and (mostly written) support materials. Since our analysis of implementation problems indicated that especially the support materials — if available — are of a poor quality, we shall focus on that component ("lessonware") of the courseware. In order to identify "high quality" characteristics, we need to clarify what functions the materials should have for the teacher.

\section{Functions and Characteristics of Courseware}

As shown in the previous sections, integration of computer use by teachers is complex and involves them in learning new roles and unlearning old ones. Implementation can be 
conceived as a learning process for the teacher in which changes are required in teaching behavior as well as in beliefs, attitudes and understanding.

A literature review of Van den Akker $(1988 \mathrm{~b}, \mathrm{c})$ on curriculum implementation, teacher planning, and general learning theories provides some answers to the question of how materials can contribute to this learning process of teachers in their initial implementation phase.

The literature on curriculum implementation reveals that in teachers' initial implementation efforts personal self-concerns dominate, changing via more task-oriented concerns to concerns about the impact of the curriculum on learners (Loucks \& Lieberman, 1983). Research indicates that this change model also applies on computer integration (Cicchelli \& Beacher, 1985, 1987; Wiske et al., 1988). Thus, at present, where most teachers are still in the initiation phase where personal survival concerns dominate, courseware materials should support the teachers by anticipating as much as possible potential user problems and by offering practical advice to prevent or solve such problems.

From research on teacher planning (Clark \& Peterson, 1986) it has become more evident that changing the practice of teaching requires more attention to the stage of pre-active planning. The lesson planning approach is of crucial importance for the lesson execution, and, ultimately, also for learning-by-reflection of the teacher afterwards. Literature on general learning theories indicates that (intensive) orienting activities yield more precise and reasoned plans for action. Courseware may activate and support teacher planning by providing a clear orientation to the teaching task, by pointing to critical features of (computer assisted) lessons and by making suggestions about how to deal with emergent problems during the instructional process.

From this analysis we may conclude that courseware, intended for teachers' initial use, should contain a large amount of procedural specifications: very accurate how-to-do-it advice focused on essential but apparently vulnerable elements of the curriculum. This means that the support materials should not only contain "technical" information about the use of the computer program, but also detailed advice about the instructional process (cf. Fullan et al., 1987). With the help of such materials, the teachers should be stimulated to a task orientation and to concrete role-taking experiences and should be supported with practical advice for successful lessons.

In order to produce such courseware, one has to follow a very careful development approach, with much attention for formative evaluation and revision of the materials. Obviously, the technical certainty of the software must be guaranteed and the program should be easy to use (Fullan et al., 1987). Special efforts have to be made to detect teachers' problems with the use of the courseware in their classroom situation. These evaluation findings should lead to the incorporation of procedural suggestions for the teachers in the support materials about how to prevent or solve such problems.

It seems desirable that the development of the software and the support materials ("lessonware") proceeds in close interaction. More or less simultaneous design, construction and evaluation activities can further the interwoveness of the different courseware components. Such an approach may also increase the chances to produce courseware that is innovative from an instructional and curricular perspective (cf. Hawkins \& Sheingold, 1986). 


\section{An Illustrative Study}

An explorative study along these lines has been done by Keursten (1988), who developed courseware for primary science. He pointed out that there is a remarkable resemblance between major implementation problems of teachers with a new approach in (activity-based) science education and the earlier discussed problems with the integration of computer use. Van den Akker (1988a, b) mentioned the following key problems for teachers in the science domain:

- complex and time-consuming lesson preparation;

- a lack of background knowledge and skills (causing a lack of self-confidence);

- great difficulties in changing the didactical role;

- insufficient view of possible learning outcomes.

In the research project of Van den Akker (1988a, b), a successful effort was made to diminish these problems by providing teachers with many, carefully tested procedural specifications in curriculum materials. Keursten (1988) applied the same sort of specifications in courseware for a series of seven lessons (on the theme "weather"; final grade of primary school), to be used by teachers who had neither experience with computer use nor with an activity-based science approach. The courseware package consisted of: written lesson materials containing subject matter information and directions for lesson preparation and execution; educational software with a very succinct manual about its operation; and some student materials.

The procedural specifications for the package were divided over the written lesson materials ("lessonware") and the software manual. In the "lessonware" the following categories were incorporated:

- general characterization of the series of lessons in terms of objectives, content, time (also division of time over different lessons), suggestions for detecting learning effects.

- background information about the subject matter so that it is not necessary for the teacher to refer to other sources during the lesson preparation.

Per lesson were included:

- a short outline of the lesson;

- suggestions for the lesson preparation, including issues like: necessary learning aids, classroom organization, structure of the lesson in keywords, personal preparation by the teacher.

- guidelines for lesson execution with suggestions for instructional activities, for classroom organization, and for guidance of the students.

The manual of the computer program consisted of:

- directions for the use of the computer (especially important for teachers without experience with computers);

- description of the objectives (short, because it is also part of the written lesson materials);

- directions for the use of software (important, as it must answer all possible questions teachers may have in using the program);

- points of attention about the siting of the computer(s). 
Two basic elements in the design approach should be underlined. First, the curricular perspective was in the forefront; the computer software was developed as a tool for realizing the formulated curriculum aims. Second, the primary focus in the elaboration of the materials was on the tasks and user problems of the teachers - and not on the possibilities of the software.

An evaluation of the use of this courseware with five teachers had positive results. The teachers were able to use the package as meant by the designers. They hardly experienced any technical problems and adequately realized the activity-based science approach. Also the reactions and learning outcomes of the students were very satisfying. A general conclusion of this study was that the characteristics of the courseware seem very appropriate to reduce implementation problems. Therefore follow-up research has been started for further investigation of this approach.

\section{Conclusion}

The integration of computer use in the instructional practice of teachers benefits by "infusable" support materials (cf. Wilson, 1988).

We would like to summarize our infusion approach as follows:

- teachers can start their computer use with short and well organized applications;

- successful use is strongly advanced by carefully designed and validated procedural specifications in the different courseware components;

- based on these successful experiences, teachers acquire clarity about the meaning and potential of the innovation, gain confidence in their own competence, and develop their own view of the appropriateness of the innovation for their students and themselves.

Without such early "high quality" experiences, teachers' judgments about the relevance and practicality of computer use can only be superficial. As Wiske et al. (1988) found, the initial reservations of teachers about computer use diminish after experiencing examples of computer use that yield clear educational benefits. A real integration of computer use in the curriculum can only be realized when teachers recognize the surplus value of computer use. Successes in the early implementation phase are crucial for motivating teachers to further activitics and to elicit commitment to the change efforts.

We have strongly concentrated our arguments on the role of products (courseware) in the process of implementation. Of course we realize - see the first part of our article - that there are many other variables at stake. But we agree with Collis (1988) that it makes sense to focus on those variables which are relatively easy to manipulate. And, within the then available options, we have strong indications that a sophisticated design of the support materials within courseware can have a great impact on implementation activities and outcomes. We presume that this impact can be increased when the use of such products is combined with inservice training (cf. OTA, 1988). Such integrated support activities seem to have the greatest potential to enable teachers to an effective integration of computer use in their classroom practice. 


\section{References}

Akker, J. J. H. van den (1988a). Ontwerp en implementatie van natuuronderwijs [Design and implementation of science education]. Lisse: Swets \& Zeitlinger.

Akker, J. J. H. van den (1988b). The teacher as learner in curriculum implementation. Journal of Curriculum Studies, $20(1), 47-55$.

Akker, J. J. H. van den (1988c, April). Product design and curriculum implementation. Paper presented at the Annual Meeting of the American Educational Research Association, New Orleans.

Balla, J., Gow, L., \& Burton, P. (1986). Computers in the teaching process and software development: Cooperation is the key. Education \& Computing, 2, 265-271.

Becker, H. J. (1986). Instructional uses of school computers: Reports from the 1985 national survey (Issue 1-6). Baltimore: Center for Social Organizations of Schools, Johns Hopkins University.

Beishuizen, J. J., Tobin, J., \& Weston, P. R. (Eds.). (1988). The use of the microcomputer in teaching and learning. Amsterdam: Swets \& Zeitlinger.

Bitter, C. G., \& Gore, K. (1986). Trends in hardware/software. Curricular implications of a "computer for every student". Computers in the Schools, 3 (2), 15-21.

Carmichael, H. W., Burnett, J. D., Higginson, W. C., Moore, B. G., \& Pollard, P. J. (1985). Computers, children and classrooms: A multisite evaluation of the creative use of micro-computers by elementary school children. Ontario: Ministry of Education.

Centre for Educational Research and Innovation (1986). New information technologies: A challenge for education. Paris: OECD.

Chomienne, M. (1988). Educational computing implementation: The case of Quebec. Computers and Education, 12 (1), 85-90.

Cichelli, T., \& Beacher, R. E. (1985). Introducing microcomputers into the classroon: a study of teachers' concerns. Journal of Educational Computing Research, 1 (1), 55-65.

Cichelli, T., \& Beacher, R. E. (1987). The use of concerns theory in inservice training for computer education. Computers and Education, 11 (2), 85-93.

Clark, C., \& Peterson, P. (1986). Teachers' thought processes. In M. C. Wittrock (Ed.), Handbook of research on teaching (3rd ed., pp. 255-296). New York: Macmillan.

Collis, B. (1988, July). Manipulating critical variables: A framework for improving the impact of computers in the school environment. Paper presented at the EURIT ' 88 conference, Lausanne, Switzerland.

Cox, M. J. (1987). Computer-assisted learning/CAL and the future. In Tj. Plomp, K. van Deursen, \& J. Moonen (Eds.), CAL for Europe (pp. 33-49). Amsterdam: North Holland.

Cox, M., Rhodes, V., \& Hall, J. (1988). The use of computer assisted learning in primary schools: Some factors affecting the uptake. Computers and Education, 12 (1), 173-178.

Crandall, D. P., and Associates (1982). People, policies and practices: Examining the chain of school improvement (Vols. I-X). Andover, MA: The NETWORK.

Cuban, L. (1986). Teachers and machines: The classroom use of technology since 1920. New York: Teachers College Press.

D’Arcy, J., \& Gardner, J. (1988). Learning from teachers: Teachers' perspectives of relevant courseware and training provision. Computers and Education, 12 (2), 321-326.

Doylc, W., \& Ponder, G. A. (1977-1978). The practicality ethic in teacher decision making. Interchange, $8(3), 1-12$

Elder, R. J., Gourlay, J., Johnstone, M., \& Wills, R. (1987). Microcomputers in primary education. In N. Rushby (Ed.), Computer based learning, selected readings (pp. 120-126). London: Kogan Page.

Emrick, J. A., \& Peterson, S. M. (1978). A synthesis of findings across five recent studies in educational dissemination and change. San Francisco, CA: Far West Laboratory.

Fullan, M. G. (1982). The meaning of educational change. New York: Teachers College Press.

Fullan, M. G, Miles, M. B., \& Anderson, S. A. (1987). Strategies for implementing microcomputers in schools: The Ontario case. Toronto, Ontario: Ministry of Education.

Hawkins, J., \& Sheingold, K. (1986). The beginning of a story: Computers and the organization of learning in classrooms. In J. A. Culbertson \& L. L. Cunningham (Eds.), Microcomputers in education (85th NSSE Yearbook, pp. 40-58). Chicago: The University of Chicago Press.

Heywood, G., \& Norman, P. (1988). Problems of educational innovation: The primary teacher's response to using the microcomputer. Journal of Computer Assisted Learning, 4, 3443.

Inspectorate (1986). Onderwijs en informatietechnologie: Stand van zaken in het schooljaar 1985/1986 [Education and information technology: State of affairs in the school year 1985/1986] (Inspectorate report No.7). The Hague: Staatsuitgeverij.

Inspectorate (1988). Het NIVO project in de scholen [The NIVO project in the schools] (Inspectorate report No. 25). The Hague: Staatsuitgeverij. 
Keursten, P. (1988). Computertoepassingen in het natuturonderwijs-curriculum [Computer applications in the science curriculuml. Enschede: University of Twente.

Knupfer, N. N. (1986). Implementation of microcomputers into the current $K-12$ curriculum: $A$ critical discussion of issues. Madison: University of Wisconsin.

Loucks, S. F., \& Lieberman, A. (1983). Curriculum implementation. In F. W. English (Ed.), Fundamental curriculum decisions (pp. 126-141). Alexandria, VA: Association for Supervision and Curriculum Development.

Mackey, B. (1987). Effective educational courseware - the microcomputer as a learning medium. In J. Moonen \& Tj. Plomp (Eds.), EURIT '86: Developments in educational software and courseware (pp. 603-610). Oxford: Pergamon Press.

Mallatratt, J. (1988). CAL: Development of an environment to support the innovation. Computer Education, $59,21-23$.

Office of Technology Assessment (1988). Power on! New tools for teaching and learning. Washington DC: Government Printing Office.

Olson, J. (1988). Schoolworlds/microworlds. Computers and the culture of the classroom. Oxford: Pergamon Press.

Olson, J, \& Eaton, S. (1986). Case studies of microcomputers in the classroom. Questions for curriculum and teacher education (Education and technology series). Ontario: Ministry of Education.

Plomp, T]., \& Akker, J. J. H. van den (1988, April). Computer integration in the curriculum: promises and problems. Paper presented at the Annual Meeting of the American Educational Research Association, New Orleans.

Plomp, Tj., Steerneman, A. H. M., \& Pelgrum, W. J. (1988). Curricular changes as a consequence of computer use. In F. Lovis \& E. D. Tagg (Eds.), Computers in education. Proceedings of the IFIP TC 3 European Conference on Computers in Education (pp. 503-508). Amsterdam: Elsevier Science Publishers.

Preece, J., \& Jones, A. (1985). Training teachers to select educational computer software: Results of a formative evaluation of an Open University Pack. British Journal of Educational Technology, 16 (1), 9-20.

Ridgway, J., Benzie, D., Burkhardt, H., Coupland, J., Field, G., Fraser, R., \& Phillips, R. (1984). Conclusions from CALtastrophies. Computers in Education, 8, 93-100.

Rogers, E. M., \& Shoemaker, F. F. (1971). Communication of innovations. A cross-cultural approach. New York: Free Press.

Sheingold, K., Martin, L. M. W., \& Endreweit, M. E. (1987). Preparing urban teachers for the technological future. In R. D. Pea \& K. Sheingold (Eds.), Mirrors of minds. Patterns of experience in educational computing (pp. 67.85). Norwood, NJ: Ablex Publishing Corporation.

Stecher, B. M., \& Solorzano, R. S. (1987). Characteristics of effective computer inservice programs. Pasadena, CA: Educational Testing Service.

Strudler, N. B., \& Gall, M. D. (1988, April). Successful change agent strategies for overcoming impediments to microcomputer implementation in the classroom. Paper presented at the Annual Meeting of the American Educational Research Association, New Orleans.

Velzen, W. G. van, Miles, M. B., Ekholm, M., Hameyer, U., \& Robin, D. (1985). Making school improvement work. A conceptual guide to practice. Leuven: Acco.

Wagshal, P. H. (1986). Computers in the schools: Lessons from television. Curriculum Review, 24 (3), 32-34.

Walker, D. F. (1986). Computers and the curriculum. In J. A. Culbertson \& L. L. Cunningham (Eds.), Microcomputers and Educution (85th NSSE yearbook, pp. 22-39). Chicago: The University of Chicago Press.

Williams, F., \& Williams, V. (1984). Microcomputers in elementary education; Perspectives on implementation. Belmont, CA: Wadsworth Publishing Company.

Wilson, B. (1988). Making sense of the future. A position paper on the role of technology in science, mathematics, and computing education. Cambridge, MA: Educational Technology Center, Harvard Graduate School of Education.

Wiske, M. S., Zodhiates, Ph., Wilson, B., Gordon, M., Harvey, W., Krensky, L., Lord, B., Watt, M., \& Williams, K. (1988). How technology affects teaching. Cambridge, MA: Educational Technology Center, Harvard Graduate School of Education.

Woodhouse, D., \& Jones, A. J. (1988). Integrating CAL with other instructional activities in schools. Computers and Education, 12 (3), 381-389. 